\title{
オン・ザ・スポット
}

\section{第25回日本医学会総会:医学展示・ 博覧会「生命(いのち)の博覧会」}

佐 藤 淑子

東京女子医科大学図書館

第 25 回日本医学会総会 : 医学展示・博覧会 「生命（いのち）の博覧会」は東京国際展示場 （東京ビッグサイト）で 1999 年 3 月 30 日から 4 月8日まで開催されました。

またこの間, 日本橋三越本店 7 階催物会場でサ テライト企画として 3 月 30 日から 4 月 4 日まで 「身近な健康とくすりの歴史展」が開催されまし た。この催しは, 一般市民が医学会総会に気軽に 参加できるようデパートで開催され，「春の院展」 之同時期に同じフロアで開催されたことああり， 会場は非常ににぎわっていました。

「身近な健康とくすりの歷史展」は日本におけ る医学の原点とくすりの関係を学びながら, 日々 の健康管理について考えるように企画され，主な 展示物は岐阜県にある内藤記念くすり博物館より 出展されていました。

病気が悪魔のしわざだと信じられ，早く治るよ うに神に祈りを捧げるのが唯一できることだった 時代から，植物のむつ毒性に注目しはじめ，それ が狩りなどに使われ，やがてある植物が特定の病 気の治療に役立つことなど, 薬草の発見から開発 の歷史まで, 展示の数々から学びとることができ ました。

さらに健康に関する講演会やハーブ・アロマテ ラピー教室, 薬草教室が開かれ, 身近にくすりや 健康のことを楽しみながら知ることができるよう になっていました。特に日本の近代医学の道を開 いたドイッ人医師シーボルトが使ったとされる薬
第25回日本医学会楼会開催配念

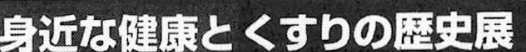
3月30日(

来る21㤝を紀を前に、日本に於ける灾学の原点とくすり、日々の健康管理について考えます。

なるほどくすりミュージアム 健康モールゾーン

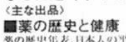

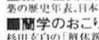

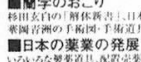
四继康への戒め

箱や消化にまつわる各臓器を擬人化し，その働き をおもしろく解説している錦絵「飲食養生鑑（い んしょくょうじょうかがみ)」には興味尽きない あのがあります。

また期間中は「日本の女医第一号荻野吟子」 「吉岡彌生の軌跡」「女性のウエルエージングとはり きゅう」の三つのパネル展示も行われていました。

荻野吟子は 1851 (嘉永 4) 年, 埼玉県妻沼町 俵瀬の旧家に生まれました。彼女の波乱にとんだ 生涯は作家・渡辺淳一の小説「花埋み」に克明に 描かれています。また医院を開業していた北海道 瀬棚町の瀬棚郷土館には遺族より寄贈された吟子 の遺品 40 点あまりが展示保存され, 荻野医院跡 地には彼女の功績を後世に伝える顕彰碑が建立さ れています。

大会展示のメイン会場は臨海副都心・有明地区 にある日本最大規模を誇る展示場, 東京ビッグサ イトでした。医学会総会初めての博覧会で, 広く 一般に公開され，なんと 31 万 7 千人を超える入 場者数を記録したそうです。

広く吹き抜けとなっている西展示棟 1 階アトリ ウムは「市民の広場」として舞台が特設され，コ ンサート, シンポジゥムNHK-BS2「健康ホット ライン」の番組生中継など多彩なイベントが催さ れました。

「社会とともにあゆむ医学一開かれた医療の世 紀へー」をテーマに 10 日間開催された展示場は 


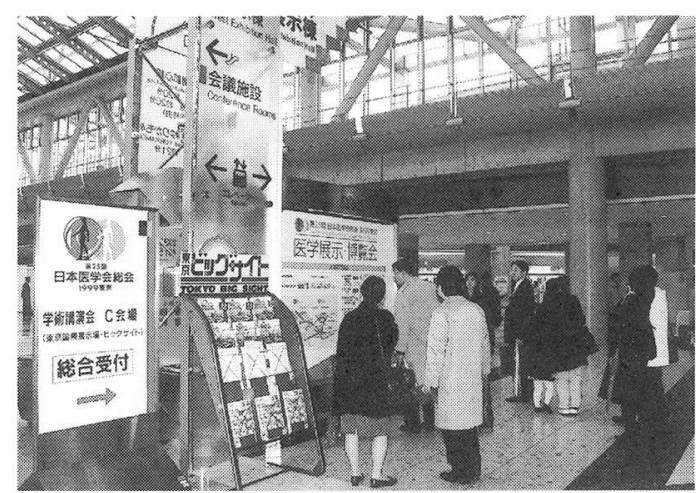

医学展示・博覧会会場 (於・東京ビッグサイト)

晴天に恵まれ，桜が満開でした。とても一日では 把握することができない壮大なテーマと展示場で, 開催期間が 1 力月あったらと惜しまれます。

会場は 5 館に分かれ，それぞれテーマをむち， 見終わると自身の体内や健康状態を知ることから， 身近な医療, 環境と健康, そして世界規模の医療 の連携と徐々に視野が広がるようになっています。

第 1 館「人と病気との戦い」では，立体音響映 像シアター「テアトル $2000 \mathrm{X}$ 年」がハイライト で，行列待ちして映像を見ました。未来の薬マイ クロマシンが悪性の肺ガンを治すというストーリー で，大音響のもと迫力満点で上映されました。人 体のミクロの世界へ観客を引き込み，マイクロマ シンがロボット的な㗢きをしてがん治療をすると いうその内容は，昔見た映画「ミクロの決死圈」を 思わせました。

セルフケアゾーンでは, 手軽に体脂肪や血圧を 測定し，骨粗鬆症の自己チェックをしたり，また なんの関連性もなくプリクラを撮ったり結構大人 あ子供む楽しめました。

第 2 館「病院探検」では, 近未来の病院内をイ メージし,これからの医療施設の在り方が提案さ れ，なかでも蓄熱式空調システムは夜間電力を利 用し, $\mathrm{CO}_{2}$ 排出量を低減する設備であり, 病院内 の楽屋裏を見るような面白さがありました。

第 3 館は, 博覧会最大面積の大規模な展示となっ

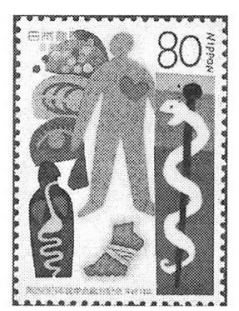

第 25 回日本医学会総会記念切手

たテーマ館で「安全都市・在宅ケア」のあと，そ の展示は環境に優しい，人に優しいといった「優 しさ」が 21 世紀に対する一つのキーワードにな ると感じさせました。

少子高齢化社会を迎えようとする我が国におい て，高齢者や患者さんだけではなく介護にあたる 家族など，すべての人たちの生活の負担をどのよ うに軽減できるかが重要な課題です。なかなか本 当のところがよくわからない点を体験しながら理 解することができ, 貴重な経験でした。「かかり つけ医」の付き合い方，看護や介護の在り方，障 害のある人や高齢者の自立生活を支援するための 機器の実際, 街や家庭でのバリアフリーの実現之 いったどれも非常に身近にせまる大事なことでし た。

第 4 館は「世界に広がる医療」，第 5 館は先に 述べたアトリウム「市民の広場」となっており， インターネット検索や, 医学, 健康図書の販売な どのコーナーを設け，一般来場者の医療に対する 知識や情報を得られる場を提供していました。

総会期間中, 記念品として様々なグッズが展示, 販売され，なかでも記念切手は人気の品でした。

4 月 2 日に「第 25 回日本医学会総会」記念切 手が発行され，わが国の医学・医療の発展に果た した日本医学会の貢献と第 25 回総会開催という 節目を記念としたものです。

最後に, 今回の原稿は総会配布資料を参考に展 示の紹介をいたしました。 